\title{
Bringing Mindfulness Practice to Leadership and Business Education
}

\author{
Vicki Fairbanks Taylor \\ Shippensburg University of Pennsylvania \\ Kathy Bishop \\ Royal Roads University
}

\begin{abstract}
Mindfulness is a learned skill developed through individual practice. Evidence on the positive outcomes associated with mindfulness has resulted in organizations adopting mindfulness programs. Leadership and business educators have sought to cultivate mindfulness in the classroom to promote learning and increase learners' awareness of their own and others' perspectives. In an attempt to enhance students' mindfulness and to draw connections between mindfulness and individual and organizational effectiveness, the authors incorporated a series of mindfulness exercises into their classes. While developed for undergraduate and graduate courses in leadership, the exercises would also be appropriate in other courses in the business curriculum.
\end{abstract}

Keywords: Mindfulness, Leadership Development, Business Education, Experiential Exercises

\section{INTRODUCTION}

Today, there exists a widely held belief that business education has failed in its mission to prepare graduates for careers in business (Ungaretti et al., 2015). Critics of business education note the focus on technical skills and discipline-based content knowledge versus developing the skills needed to succeed in today's business environment (Arbaugh \& Hwang 2015; Salas, Wildman, \& Piccolo, 2009). According to Yang and Goralski (2016), a large body of research suggests that mindfulness and contemplative practices are critical skills for business and leadership and research by Brown and Ryan (2003) indicates that individual mindfulness can be increased with training and practice. Hence, mindfulness may prove relevant to undergraduate and graduate leadership and business education, especially when addressing topics such as emotional intelligence, organizational culture, employee wellness, stress management, ethics, diversity, and employee work attitudes. This article recommends incorporating mindfulness exercises into the leadership and business classroom to help students gain greater awareness of their level of mindfulness and provide them with an experiential understanding of mindfulness and its potential benefits. It includes a brief discussion of mindfulness and evidence supporting the cultivation of mindfulness in organizations and business education. Included are a selection of mindfulness exercises that can be incorporated in the classroom along with suggestions for facilitating mindfulness practice. 


\section{THE CONCEPT OF MINDFULNESS}

Mindfulness, described as attention to the present moment, involves external awareness and attention to one's mind (Sutcliffe, Vogus, \& Dane, 2016) without reactivity or judgment (Glomb, Duffy, Bono, \& Yang, 2011). Theoretically, mindfulness is related to the idea of reflective self-consciousness and being aware of subjective experiences, behavior, and the immediate environment (Brown, Ryan, \& Cresswell, 2007). Hence, it involves attending to the present moment while being aware of external and internal phenomena (Dane, 2011). Hougaard and Carter (2016) define mindfulness as having two components, focus and awareness. Focus is defined as "the ability to concentrate on what you're doing in the moment," and awareness is defined as the "ability to avoid or reduce distractions" (np). In sum, mindfulness entails non-judgmental awareness of one's assumptions and perceptions and the emotions and attitudes attached to them (Tuleja, 2014). In contrast, mindlessness, characterized by a lack of awareness of the present moment, encompasses rumination on past errors (Watkins, 2008), attentional distractibility (Creswell, 2017), automatic pilot functioning (Creswell, 2017; Kang, Gruber, \& Gray, 2013), and reactive future planning (Langer \& Moldoveanu, 2000).

Mindfulness has gained interest among organizational researchers and practitioners (McGhee \& Grant 2015). A growing body of research suggests that mindfulness practices significantly benefit individual and workplace outcomes, including performance, relationships, and employee well-being. (For a systematic review see Lomas et al., 2017.) Glomb and colleagues (2011) found that mindfulness improved social relationships, increased resiliency, and improved task performance. Other researchers identified positive relationships between mindfulness and job performance (Dane \& Brummel, 2014; Good, et al. 2016); work engagement (Petchsawang \& McLean, 2017); communication quality (Burgon, Berger, \& Waldron, 2000); the fostering of healthy organizational cultures (Schuyler, Taylor, \& Wolberger, 2018); and emotion regulation, job satisfaction, and decreased emotional exhaustion (Hülsheger, Alberts, Feinholdt, \& Lang, 2013). Davis and Hayes (2011) found evidence that practicing mindfulness positively influenced emotion regulation, relationship satisfaction, conflict management, empathy, stress reduction, the ability to manage distractions, and employee well-being.

Leadership and business educators have also advocated for mindfulness training (Dumas, 2007; Kuechler \& Stedham, 2018; Reitz \& Chaskalsonas, 2016), suggesting that enhanced awareness of self and others helps leaders and students more effectively deal with complex and dynamic organizational realities. Business schools such as New York University's Stern School of Business have developed mindfulness initiatives to build students' leadership skills and enhance their emotional intelligence (Kim \& Shy, 2015). Other management educators have discovered that incorporating mindfulness into the business curriculum increased students' acceptance of novel perspectives (Kuechler \& Stedham, 2018). Relative to leadership development, studies suggest training and practice in mindfulness resulted in increases in leader resilience, the capacity for collaboration, and the ability to lead in complex conditions (Reitz \& Chaskalson, 2016). Research also suggests that mindfulness may support the development of authentic leadership characteristics (Baron, 2016).

\section{INTRODUCING MINDFULNESS PRACTICES IN THE CLASSROOM}

As educators, we have introduced mindfulness as a topic and practice in our undergraduate and graduate leadership courses. In the undergraduate leadership course, the instructor presented mindfulness as a workplace spirituality practice associated with positive organizational and individual-level outcomes such as heightened self-awareness, improved relationships, increased self-regulation, and stress reduction. Simple mindfulness exercises facilitated in the classroom, such as breathing exercises, purposeful pauses, body scanning, and mindful listening, provided students with an experiential understanding of the benefits of mindfulness practice. Each practice was related to one or more leadership concepts addressed in the course, including emotional intelligence, communication, conflict management, employee coaching, and change management. 
In the graduate courses in leadership, the instructor introduced mindfulness as a foundational element in crafting a personal leadership practice, attending to leading self, teams, and organizations. Students were invited to create space and time for mindful practice, both proactively and in the moment. In this way, they were able to develop as reflective practitioners, both reflecting on action and in action (Schön, 1984). One of the ideas discussed in class was the impact of technology on mindfulness. Identifying the constant draw of electronic devices on people's attention, Macy and Brown (2014) noted that "we drown in bits of information that engulf our self-awareness and dilute our connection to the real world around us. Not only is our attention hijacked, but our imagination as well, diminishing our capacity to envision what we might yet cocreate" (p. 27). Mindfulness was offered as a way to reclaim self-awareness, engage with the real world, and play in imagination. Mindfulness activities ranged from individual experiences, engaging with others in the classroom, going out in nature, and dreaming new possibilities.

In both the undergraduate and graduate classes, students were presented with the body of research on the benefits of mindfulness to the individual and the organization. In addition, students completed an initial assessment of mindfulness, such as the Kentucky Inventory of Mindfulness Skills (Baer, Smith, \& Allen, 2006) or the Mindful Attention and Awareness Scale (MAAS; Brown \& Ryan, 2003). Both scales can be accessed using the hyperlinks found in Appendix A. (If instructors wish to assess whether mindfulness increases as a result of introducing mindfulness practices in a course, the assessment should be given at the beginning of the semester and again following the completion of the course.) The use of reflective journaling was also encouraged to increase students' understanding of mindfulness practice and its benefits as well as to create meaning from their experiences. For example, after a simple breathing exercise, students were asked to write down how they felt before and after the activity. Insights students gained through personal reflection include focus, calmness, and a greater sense of emotional control. Students were encouraged to set aside a regular time and space for mindfulness practice. In this way, students could deepen their understandings of how mindfulness might enhance personal growth and develop leadership presence and productivity in organizations. As learners and future leaders consider their connection to self and interconnection with others, their organizations, and the broader environment, they can more consciously choose how to show up and lead change.

\section{INSTRUCTIONS FOR RUNNING MINDFULNESS EXERCISES}

\section{Learning Objectives}

The learning objective for each mindfulness practice session includes the following: (1) to increase self-awareness and acceptance, (2) to acquire an experiential understanding of mindfulness practices; and, (3) to reflect upon the exercise to gain personal insight on the practice of mindfulness. In the graduate leadership course, the learning objectives also included reflecting on insights gained around understanding self as leaders and leadership in general as a result of the practice of mindfulness.

\section{Selecting a Mindfulness Exercise}

This section presents a selection of mindfulness exercises instructors can incorporate into their courses (see Table 1). Each exercise is briefly described with references, so interested individuals can further explore the exercise prior to adoption. In addition to the activities listed below, the Internet offers a wealth of resources. Using the search terms "mindfulness exercises for beginners" in Google resulted in over 28,000,000 results. Video and audio resources were also identified in the Google results, which may be useful resources for encouraging practice outside of the classroom. 
TABLE 1

SAMPLE MINDFULNESS EXERCISES

\begin{tabular}{|c|c|c|}
\hline Exercise & Brief Descriptions & Resource/Script \\
\hline Simple Breathing Exercise & $\begin{array}{l}\text { An entry-level meditation where } \\
\text { participants focus their attention on } \\
\text { their breath with the goal of focusing } \\
\text { and calming the mind while grounding } \\
\text { themselves in the present moment } \\
\text { (instead of being lost in thoughts). }\end{array}$ & $\begin{array}{l}\text { http://projects.hsl.wisc.ed } \\
\text { u/SERVICE/courses/whol } \\
\text { e-health-for-pain-and- } \\
\text { suffering/Script-Mindful- } \\
\text { Breathing.pdf }\end{array}$ \\
\hline $\begin{array}{l}\text { Body Scan - Mindfulness of } \\
\text { Sensations }\end{array}$ & $\begin{array}{l}\text { A mindfulness exercise in which } \\
\text { participants practice bringing } \\
\text { nonjudgmental, compassionate present } \\
\text { moment awareness to each part of their } \\
\text { body. }\end{array}$ & $\begin{array}{l}\text { http://projects.hsl.wisc.ed } \\
\text { u/SERVICE/courses/whol } \\
\text { e-health-for-pain-and- } \\
\text { suffering/Script-Body- } \\
\text { Scan.pdf }\end{array}$ \\
\hline The Raisin Meditation & $\begin{array}{l}\text { An introductory mindfulness exercise } \\
\text { involving the deliberate eating of a } \\
\text { single raisin. It illustrates how mindful } \\
\text { awareness can be brought to every } \\
\text { aspect of daily life and demystifies the } \\
\text { process of mindfulness meditations. }\end{array}$ & $\begin{array}{l}\text { https://www.uaex.edu/hea } \\
\text { lth-living/extension- } \\
\text { homemakers/Mindfulness } \\
\text {.pdf }\end{array}$ \\
\hline Mindful S.T.O.P & $\begin{array}{l}\text { The Mindful S.T.O.P. is a four-step } \\
\text { practice that helps people engage in } \\
\text { more effective behaviors and } \\
\text { experience less stress in response to } \\
\text { challenging situations. }\end{array}$ & $\begin{array}{l}\text { https://eclkc.ohs.acf.hhs.g } \\
\text { ov/sites/default/files/pdf/e } \\
\text { arlyedu-mindful- } \\
\text { practices-handout.pdf }\end{array}$ \\
\hline Mindful R.A.I.N & $\begin{array}{l}\text { A more advanced mindfulness practice } \\
\text { that enables mindfulness in difficult } \\
\text { times and provides a strategy (R.A.I.N) } \\
\text { to attend to emotions. }\end{array}$ & $\begin{array}{l}\text { https://www.tarabrach.co } \\
\text { m/wp- } \\
\text { content/uploads/pdf/RAI } \\
\text { N-of-Self- } \\
\text { Compassion2.pdf }\end{array}$ \\
\hline $\begin{array}{l}\text { Compassion for self and } \\
\text { others }\end{array}$ & $\begin{array}{l}\text { A mindfulness practice that generates } \\
\text { compassion for self and others; } \\
\text { discharges negative emotions. }\end{array}$ & $\begin{array}{l}\text { https://chrisgermer.com/w } \\
\text { p- } \\
\text { content/uploads/2017/02/ } \\
\text { MSC-Compassion-for- } \\
\text { Self-and-Others.pdf }\end{array}$ \\
\hline Mindful Walking & $\begin{array}{l}\text { As participants focus their attention on } \\
\text { walking in the world, they are invited } \\
\text { to gather their awareness, move out of } \\
\text { autopilot, and become present with } \\
\text { their surroundings. }\end{array}$ & $\begin{array}{l}\text { https://slco.org/uploadedF } \\
\text { iles/depot/services/fHealt } \\
\text { hyLifestyles/Mindful\%20 } \\
\text { Walking\%202.pdf }\end{array}$ \\
\hline
\end{tabular}




\begin{tabular}{|l|l|l|}
\hline Exercise & Brief Descriptions & Resource/Script \\
\hline Collective Breathing & $\begin{array}{l}\text { An exercise to engage a group in } \\
\text { breathing together; simultaneously } \\
\text { bringing awareness of self and others. }\end{array}$ & See Appendix B.1 \\
\hline Eye-to-Eye & $\begin{array}{l}\text { Pairs of people look into each other's } \\
\text { eyes to connect with themselves and } \\
\text { others. }\end{array}$ & See Appendix B.2 \\
\hline Nature-based activities & $\begin{array}{l}\text { Participants imagine themselves as a } \\
\text { mountain to gain strength and wisdom. } \\
\text { Participants go into nature, and } \\
\text { mindfully engage with their } \\
\text { surroundings; gaining wisdom from } \\
\text { nature, and making symbolic } \\
\text { connections to their lives and } \\
\text { leadership. }\end{array}$ & $\begin{array}{l}\text { meditation.pdf } \\
\text { See Appendix B.3 } 3\end{array}$ \\
\hline
\end{tabular}

In addition to having a repertoire of activities to draw upon, instructors are encouraged to address foundational elements when bringing mindfulness practice into the classroom, namely, instructor preparedness, creating the atmosphere, debriefing the exercise, and considering potential challenges.

\section{Instructor Preparedness}

The key to preparation is for the instructor to test out the mindfulness exercise first to see how it lands personally. Instructors need to know how to conduct the exercise, along with the challenges or insights of the activity. Ideally, mindfulness exercises should be taught by instructors who have regular mindfulness practices (Kuechler \& Stedham, 2018). Instructors with limited mindfulness practice experience are encouraged to form alliances with mindfulness professionals on their campuses or within their communities (Kuechler \& Stedham, 2018). Organizations like the Association for Contemplative Mind in Higher Education offer resources and opportunities to network with like-minded academics interested in incorporating contemplative approaches to teaching. Additionally, video-guided narratives of mindfulness exercises can be located using an internet search to assist instructors new to mindfulness practice.

Another essential preparation is becoming centered and grounded before class. One of the authors, Bishop, has found a useful strategy of taking a few minutes prior to class to sit, breathe deeply, connect with her internal and external experience, and focus on the purpose of mindfulness exercise and envision its success. By preparing for a mindfulness exercise in this manner, instructors address the three fundamental components of mindfulness practice: (a) intention, (b) attention, and (c) attitude (Shapiro, Carlson, Astin, \& Freedman, 2006). Walking into a mindfulness class calm and focused models the way for learners and sets the tone for the mindfulness exercise.

\section{Creating the Atmosphere}

Instructors should seek to create an atmosphere in which participants feel comfortable, or at least are not worried about or resistant to engaging in mindfulness. Elements of creating the atmosphere include setting the room and preparing the students both cognitively and emotionally. In setting the room prior to the exercise, a variety of choices exist. For example, lights can be dimmed, soft music played, and an incense or oil diffuser turned on (as long as no allergies are in the class). Chairs can be arranged in a circle or removed altogether, with students sitting on the floor on mats and cushions (with options given for students who might not be able to sit on the floor). 
To prepare the students, instructors can begin by offering a brief overview of what mindfulness is and why it can be a powerful practice. Explicit connections to the classroom topic and learning outcomes should also be made, so students have a big-picture overview of what to expect. Another element to consider is how to attend to students' emotional needs. Student should be instructed to be aware of any mental content as it occurs in consciousness on a moment-to-moment basis along with non-judgmental acceptance of it (Bishop et al. 2004). Instructors should consider having a conversation about co-creating safe spaces (Kisfalvi \& Oliver, 2015), brave spaces (Arao \& Clemens, 2013) or "spaces of grace, where we honor people wherever they are and trust that the process will deepen our understandings and connections" (Bishop, Etmanski, Dominguez, Page, \& Heykoop, 2019, p. 6).

After the introductory conversation, a simple invitation can be given to students asking them to be curious and letting them know that they have the ability to choose the depth and breadth of their experience; that the space is like a laboratory to test and try out the activity in which "everything belongs" (Rohr, 2013, p. 16). It would also be important to let students know that after the exercise the learning will be harvested with a debrief; alerting them to the upcoming opportunity to reflect upon the experience. Once students are prepared with a comfortable setting, an overview of what is to come, and the invitation to honor who they are and each other in the process, the exercise can begin. Guide the activity using your normal speaking voice and volume and model how to be present in each moment of the exercise without directing a specific outcome (Wolf \& Serpa, 2015). For more information on leading mindfulness exercises, see Wolf and Serpa (2015), A Clinician's Guide to Teaching Mindfulness.

\section{Debriefing the Exercise}

After experiencing the activity, a crucial element is to debrief the exercise with students by inviting them to explore and reflect upon their experience. Key elements of the debrief include allowing students time for personal reflection, sharing with others, and sharing as a whole group. All or some of these elements can be used depending on time and student and instructor preference. An example of a debrief format is as follows: (1) Pause after the activity and let students have a minute of silence. A minute of silence enables students to come back from their experience and be present in the group. (2) Reflect upon the experience. Students could be invited to journal following the exercise or asked to "pair and share" by turning to the person next to them and sharing one impression about the activity. Alternatively, all participants might stand or sit in a circle so they can all see each other. Circles create a sense of intimacy among participants rather than having all the discussion directed at the instructor. The instructor can then harvest the experience and wisdom of everyone in the room by asking a series of debriefing questions. Debriefing questions can be both process and content-oriented, as well as more general or directive and focused. Examples of general questions include the following: What was that like for you? What came up for you either personally or symbolically? Did anything surprise you? Examples of more directive and focused questions include: How can being more mindful lead to [insert relevant class concept]? How might you apply what you learned today to your leadership practice, organization, or [class topic]?

Often the debrief becomes a rich learning opportunity as students recognize a full spectrum of experiences. Sometimes students love the activity and gain moments of insight while others are frustrated by or indifferent to the activity. This opens up a dialogue for deeper exploration and different ways of thinking about and being with mindfulness, both individually and collectively.

\section{Potential Challenges}

Potential challenges that can arise during or post a mindfulness activity relate to focus and selfawareness. Sometimes it is difficult for students to focus on the activity. As a facilitator, it helps to normalize all experiences and urge students to try the activity as it is or to make personal adaptations as needed. To minimize external interruptions, an instructor should close doors. If students are asked to close their eyes, an instructor can let them know that his or her eyes will remain open to oversee the activity. Alternatively, instructors may choose to close their eyes and open them occasionally as they practice mindfulness along with the participants. To proactively address unexpected interruptions that could disrupt students' attention and focus, instructors can let students know that if a noise takes their attention, 
it can be used as an opportunity to go deeper into the mindfulness exercise rather than being pulled out of it.

As students turn inward and become more self-aware, the content, thoughts, imagery, physical sensations, or feelings that occur may be unpleasant. Thus, it is crucial for the instructor to reassure the student and normalize the experience by encouraging non-judgmental observance and acceptance on a moment-by-moment basis (Wolf \& Serpa, 2015). Gently remind students to maintain an open, compassionate attitude and the willingness to let things be just as they are (Germer 2005). According to Gilmore \& Anderson (2011), it is not enough to tolerate emotional reactions when conducting experiential exercises; instead, the instructor needs to help bring meaning to the experience. Depending on what emerges, an instructor could suggest talking together one-on-one after class. The instructor should follow up to ensure the student is okay and refer the individual to resources if they need further support. Although any experiential activity runs the risk of unanticipated happenings, the authors have found that as we continue to offer mindfulness practices to our students and take care to be mindful personally and within the classroom, challenges can be turning points for growth and compassionate acceptance.

\section{CONCLUSION}

An accumulating body of evidence suggests that cultivating mindfulness in organizations yields benefits for organizations and their members. Good and colleagues (2016) suggest that individual and organizational effects of mindfulness make it an attractive management tool, and training in mindfulness "offers promise in the fostering of key role attributes" (p. 134). Our experiences in introducing mindfulness practices in undergraduate and graduate leadership classes serve as anecdotal support of the benefits of mindfulness in leadership and business education. Students' reflections include feeling a greater sense of focus, peace and calm, and emotional control. Furthermore, students have spoken to experiencing a deeper connection with others and how the experience has bonded them together as a group. Students have also shared how a particular mindfulness activity caused them to have an epiphany in which insight and future actions have resulted. For example, one graduate student experienced a mindfulness activity that involved the whole class wandering outdoors around the campus grounds silently and mindfully for 30 minutes. In the debrief, the student reported that his epiphany was "to remember to stop and smell the roses." The student had walked through the rose garden and suddenly found himself smelling the roses. He made the symbolic connection to his life and leadership. He revisited his priorities and how he was leading his team and set new strategies in place for how he wanted to show up and lead. As leadership and business educators, we can support student development by bringing mindfulness activities into the classroom. As students experience mindfulness, they can then consider how this practice can ripple out into their lives and the lives of others.

\section{REFERENCES}

Arao, B., \& Clemens, K. (2013). From safe spaces to brave spaces: A new way to frame dialogue around diversity and social justice. In L. M. Landreman (Ed.), The art of effective facilitation: Reflections from social justice (pp. 135-150). Sterling, VA: Stylus Publications.

Arbaugh, J.B., \& Hwang, A. (2015). What are the 100 most cited articles in business and management education research, and what do they tell us? Organization Management Journal, 12, 154-175.

Arnold, R. D., \& Wade, J. P. (2015). A definition of systems thinking: a systems approach. Procedia Computer Science, 44, 669-678.

Atleo, E. R. (Unmeek). (2004). Tsawalk: a Nuu-chah-nulth worldview. Vancouver BC: UBC Press.

Baer, R. A., Smith, G. T., \& Allen, K. B. (2004). Assessment of mindfulness by self-report: The Kentucky Inventory of Mindfulness Skills. Assessment, 11, 191-206.

Baron, L. (2016). Authentic leadership and mindfulness development through action learning. Journal of Managerial Psychology, 31(1), 296-311. http://dx.doi.org/10.1108/JMP-04-2014-0135 
Bishop, K., Etmanski, C., Dominguez, B., Page, B., \& Heykoop, C. (2019, Spring) Narrative métissage as an innovative engagement practice. Engaged Scholar Journal, 5(2), 1-17.

Bishop, S. R., Lau, M., Shapiro, S., Carlson, L., Anderson, N., Carmody, J., et al. (2004). Mindfulness: A proposed operational definition. Clinical Psychology: Science and Practice, 11, 230-241.

Borton, T. (1970) Reach, touch, and teach: Student concerns and process education. New York, NY: McGraw-Hill.

Brown, K.W., \& Ryan, R. M. (2003). The benefits of being present: Mindfulness and its role in psychological well-being. Journal of Personality and Social Psychology, 84, 822-848.

Brown, K.W., Ryan, R.M., \& Cresswell, J.D. (2007). Mindfulness: Theoretical foundations and evidence for its salutary effects. Psychological Inquiry, 18, 211-237.

Burgoon, J.K., Berger, C.R., \& Waldron, V. R. (2000). Mindfulness and interpersonal communication. Journal of Social Issues, 56, 105-127. http://dx.doi.org/10.1111/0022-4537.00154

Creswell, J.D. (2017). Mindfulness Interventions. Annual Review of Psychology, 68, 491- 516.

Daft, R., \& Lengel, R. (2000). Fusion leadership:Unlocking the subtle forces that change people and organizations (1st paperback ed.). San Francisco, CA: Berrett-Koehler.

Dane, E. (2011). Paying attention to mindfulness and its effects on task performance in the workplace. Journal of Management, 37, 997-1018.

Dane, E., \& Brummel, B. (2014) Examining workplace mindfulness and its relations to job performance and turnover intention. Human Relations, 67, 105-128.

Davis, D.M., \& Hayes, J.A. (2011). What are the benefits of mindfulness? A practice review of psychotherapy-related research. Psychotherapy, 48, 198-208. https://doi.org/10.1037/a0022062

Dumas, C. (2007). Cultivating mindfulness in management education. International Journal of Learning, 14(4), 53-60.

Etmanski, C., Fulton, M., Nasmyth, G., \& Page, M. B. (2014). The dance of joyful leadership. In K. Goldman Schuyler, J. E. Baugher, K. Jironet, \& L. Lid-Falkman (Eds.), Leading with spirit, presence, and authenticity (pp. 91-108). San Francisco, CA: Jossey-Bass.

Germer, C. K. (2005). Mindfulness: What is it? What does it matter? In C. K. Germer, R. D. Siegal, \& P. R. Fulton (Eds.), Mindfulness and Psychotherapy. New York: Guilford Press

Gilmore, S., \& Anderson, V. (2011). Anxiety and experience-based learning in a professional standards context. Management Learning, 43, 77-95.

Glomb, T. M., Duffy, M. K., Bono, J. E., \& Yang, T. (2011) Mindfulness at work. Research in Personnel and Human Resources Management, 30, 115-157.

Good, D. J., Lyddy, C. J., Glomb, T. M., Bono, J. E., Brown, K. W., Duffy, M. K., Baer, R. A., Brewer, J. A., \& Lazar, S. W. (2016). Contemplating mindfulness at work. Journal of Management, 42, 114-142. https://doi.org/10.1177/0149206315617003

Hougaard, R., \& Carter, J. (2016). How to practice mindfulness throughout your workday. Harvard Business Review Digital Articles, 2-4. Retrieved from

http://search.ebscohost.com/login.aspx?direct=true\&AuthType=ip,sso\&db=bth\&AN=118685932 $\&$ site $=$ ehost-live \&scope $=$ site

Hülsheger, U., Alberts, H., Feinholdt, A., \& Lang, J. (2013). Benefits of mindfulness at work: The role of mindfulness in emotion regulation, emotional exhaustion, and job satisfaction. Journal of Applied Psychology, 98, 310-325.

Kang, Y., Gruber, J., \& Gray, J.R. (2013). Mindfulness and de-automatization. Emotion Review, 5, 192201.

Kefalas, A.G. (2011). On systems thinking and the systems approach. World Futures, 67, 343-371.

Kim, C., \& Shy, Y. (2015). Why NYU's B-school teaches mindfulness. Harvard Business Review Digital Articles, 2-4. Retrieved from https://hbr.org/2015/12/why-nyus-b-school-teaches-mindfulness

Kisfalvi, V., \& Oliver, D. (2015). Creating and maintaining a safe space in experiential learning. Journal of Management Education, 39, 713-740.

Kuechler, W., \& Stedham, Y. (2018). Management education and transformational learning: The integration of mindfulness in an MBA course. Journal of Management Education, 42, 8-33.

110 Journal of Leadership, Accountability and Ethics Vol. 16(5) 2019 
Langer, E.J., \& Moldoveanu, M. (2000). The construct of mindfulness. Journal of Social Issues, 56, 1-9.

Lomas, T., Medina, J.C., Ivtzan, I., Rupprecht, S., Hart, R., \& Eiroa-Orosa, F.J. (2017). The impact of mindfulness on well-being and performance in the workplace: An inclusive systematic review of the empirical literature. European Journal of Work and Organizational Psychology, 26, 492-513. http://dx.doi.org/10.1080/1359432X.2017.1308924

Macy, J., \& Brown, M. (2014). Coming back to life. Gabriola Island, BC: New Society.

McGhee, P., \& Grant P. (2015). The influence of managers' spiritual mindfulness on ethical behaviour in organisations. Journal of Spirituality, Leadership and Management, 8, 12-33.

Petchsawang, P., \& McLean, G.N. (2017). Workplace spirituality, mindfulness meditation, and work engagement. Journal of Management, Spirituality \& Religion, 14, 216-244. http://dx.doi.org/10.1080/14766086.2017.1291360

Reitz, M., \& Chaskalson, M. (2016). How to bring mindfulness to your company's leadership. Harvard Business Review. Retrieved from https://hbr.org/2016/12/how-to-bring-mindfulness-to-yourcompanys-leadership

Rohr, R. (2013). Everything belongs. New York, NY: Crossroads.

Salas, E., Wildman, J.L., \& Piccolo, R. (2009). Using simulation-based training to enhance management education. Academy of Management Learning \& Education, 8, 559-573.

Schön, D. (1984). The reflective practitioner: How professionals think in action. New York, NY: Basic Books.

Schuyler, K.C., Taylor, M.O., \& Wolberger, O.M. (2018). Bringing mindfulness and joy to work: Action research on organizational change. In J. Neal (ed) Handbook of personal and organizational transformation. Cham, Switzerland: Springer https://doi.org/10.1007/978-3-319-29587-9 27-3

Senge, P. M. (2006). The fifth discipline: The art \& practice of the learning organization. New York, NY: Currency/Doubleday.

Shapiro, S.L., Carlson, L.E., Astin, J.A., \& Freedman, B. (2006). Mechanisms of mindfulness. Journal of Clinical Psychology, 62, 373-386.

Sutcliffe, K.M., Vogus, T. J., \& Dane, E. (2016). Mindfulness in organizations: a cross-level review. Annual Review of Organizational Psychology and Organizational Behavior, 3, 55-81.

Tuleja, E.A., (2014). Developing cultural intelligence for global leadership through mindfulness. Journal of Teaching in International Business, 25, 5-24.

Ungaretti, T., Chomowicz, P., Canniffe, B.J., Weiss, E., Johnson, B., Dunn, K., \& Cropper, C. (2009). Business + design: Exploring a competitive edge for business thinking. S.A.M. Advanced Management Journal, 73, 4-11.

Yang, C., \& Goralski, M. (2016). Mindfulness and its pedagogical application in business education. Journal of International Business Disciplines, 11(2), 15-28.

Watkins, E. (2008). Constructive and unconstructive repetitive thought. Psychological Bulletin, 134, 163206.

Wolf, C., \& Serpa, G. (2015). A clinician's guide to teaching mindfulness: The comprehensive sessionby-session program for mental health professionals and health care providers. Oakland, CA: New Harbinger Publications, Inc. 


\section{APPENDIX A: MINDFULNESS ASSESSMENTS}

The Mindfulness Attention Awareness Scale (MAAS; Brown \& Ryan, 2003) is a 15-item scale designed to assess a core characteristic of dispositional mindfulness.

https://ggsc.berkeley.edu/images/uploads/The_Mindful_Attention_Awareness_Scale_-_Trait_(1).pdf

The KIMS is a 39-item self-report inventory that is used for the assessment of mindfulness skills. http://www.mindfulness-extended.nl/content3/wp-content/uploads/2013/07/KIMS-E-EN.pdf

\section{APPENDIX B: MINDFULNESS EXERCISES SCRIPTS BY KATHY BISHOP}

Systems thinking (Arnold \& Wade, 2015; Atleo, 2004; Senge, 2006; \& Kefalas, 2011) informs my practice of mindfulness. As a result, I engage in mindfulness exercises that expand beyond my own experience, intentionally engaging and teaching mindfulness within the community and nature. I offer three following scripts as examples:

\section{B.1: Collective Breathi}

Facilitator says the following: Let's all stand in a circle. This way, we can look and see everyone in the room. We are going to take three shared breaths together. I invite you to be mindful of your own breathing and the breathing of others in the room. In a moment, we are going to breathe in and breathe out, together, for three shared breaths. As you breathe in and breathe out, be sure to watch what is happening in the circle. Be mindful of the group's collective rhythm. Let's begin."

As facilitator, model the way, by breathing in slowing, with the group, tracing your eyes around the circle and looking at participants, and breathing out when it feels right with the group.

\section{What to Expect}

Within Royal Roads University School of Leadership Studies, our faculty engage in mindfulness practices intentionally (see Etmanski, Fulton, Nasmyth \& Page, 2014). Once, three colleagues (Dr. Catherine Etmanski, Dr. Cheryl Heykoop, and Dr. Guy Nasmyth) decided to connect each morning through a practice that came from one of Catherine's yoga teachers, Jennifer Piercy. This practice was to engage in three shared breaths. They expanded this practice to their students, by starting class with everyone doing three shared breaths together. Since then, the practice has grown across the school and beyond. Once when Catherine, Cheryl and I were facilitating a conference presentation with two Indigenous colleagues (Marcia Dawson and Christine Webster), Marcia suggested that we do four collective breaths with participants, given that in many Indigenous cultures, the number four is a sacred practice that honors ancestral teachings such as the four directions.

Another time, when I was facilitating a mindfulness activity at the Management and Organizational Behavior Teaching Conference in the United States, I initiated the collective breathing exercise with 40 participants. I hadn't set the activity up clearly per the script and found that the group did not collectively share in four breaths. Instead, some people had their eyes closed, others breathed on their own, and I couldn't get into sync. I stopped the activity and expressed my experience and apologized for not clearly setting up the activity. I asked, "What do you think we need to make this work?" A participant called out that what we needed was a leader to count the breaths. People in the circle nodded in agreement. I asked, "What would happen if we didn't have a leader but collectively lead the process?" Participants, on the whole, expressed doubt that this was impossible. I invited us to try. With eyes open and mindful of self and others, we did four collective breaths. The participants were amazed that it was possible. We had a fruitful dialogue about what this might mean to how we approach leadership in general, through our mental models, expectations, and actions, as well as how groups can and do move together towards a shared goal. 


\section{B.2: Eye-to-Eye}

Facilitator says the following: Before we begin, I want to highlight that any experiential activity we do is an opportunity and an invitation. It is an opportunity for you to experience something in a different way, in which we will then connect back to the topic at hand. As an invitation, no one is made to do anything. Know that you have the right to how much you decide to challenge yourself when doing an activity. Challenging yourself does not mean opting out from the group. Know that there are different ways to participate, such as being an observer, in which you offer feedback. However, the power to participate rest with you.

Begin, just to make sure what I said landed the way I meant it to, who does the power to participate rest with? What does participation look like?" (After clarifying with the group then begin the activity.)

\section{Activity Instructions}

Divide the group in half. If there are 20 people, have ten people to come to the center of the room and form a circle. Typically, people make a circle facing inwards. If that is the case, ask the people in the circle, to please turn outward. Then turn to the others in the room and say, everyone, please partner up with someone in the circle.

The facilitator says: For our first activity, we are going to do a simple handshake. The person on the outer circle will say, "Hi. I am (give your name), nice to meet you." The person on the inner circle will respond, "Nice to meet you, I am (give your name)." Once you have done this, please say nothing more. Just wait in silence.

Next, instruct the group as follows: When I will say, "switch," the outer circle will move to the left while the inner circle stands still. Shake hands and introduce yourself to the new person. I will keep saying switch, and you will keep meeting new people until you are back with the person you started with. Any questions? All clear? Okay, let's begin.

Watch the group and say "switch" after the pairs finish their introductions. When the original pair are back together, the facilitator say: Great, that was easy, right?! Okay, now we are going to do a slight variation. This time, I want you to reach out and grasp the person's hand, as you did with the handshake, but instead of saying anything, just continue to hold the handshake, looking into your partner's eyes, until I say switch. The one rule is no talking. This activity is done in silence. Any questions? All clear? Okay ready. Let's begin.

Using a timer, every 45 seconds, say, "switch." If there is any talking, remind participants of the notalking rule.

Debrief the exercise loosely following Borton's (1970) process model based on three simple questions: What? So What? Now What? Starting with what did we do? Next ask, so what happened for you either personally or symbolically? And then, how might the insights you gained from this activity be applied to your leadership (or another class topic)? Typically, the notion of time comes up, in which time goes fast with some partners and slow with others. The consistent 45 -second switch enables us to deconstruct conditions that cause us to experience time differently with different people.

\section{What to Expect}

This is a powerful activity to debrief. It serves in helping students to become mindful of self (what they are thinking, feeling, and doing) and in relation to others. I deliberately sequence the activity to allow people to do something familiar and then to push their comfort zones around something not usually done. I have found that some students are challenged by looking into other's eyes, either personally, or culturally (because some cultures deem looking directly into another person's eyes is considered rude). I always begin by explaining the invitation, and that the power rests with individuals to participate. And, I ask the group to repeat back what I said. I ask for the repeat-back because once I had a student who was severely distressed by the activity. When we talked later, she said that the worst part was that she had no choice in doing the activity. We were able to work through this issue when she heard from other students 
that the activity was an invitation. The student was able to gain new insights into her responsibility in taking care of self and being present to what is asked of in the moment. As a facilitator, I learned not to assume everyone understood the activity and as a result, put in the strategy of always having participants repeat back the invitation before beginning the activity.

\section{B.3: Back to Nature}

For this activity, I go to various spaces in nature, such as a forest, a garden, or on the beach.

\section{Activity Instructions}

Facilitator say the following: In a moment, you are going to have thirty minutes to wander in nature. Please do this silently and be open to what nature may have to tell you about your leadership (or another class topic). Please be mindful not to disturb your colleagues in this process. As a way to begin, I am going to read a Chinese parable. When I am finished reading, I will gesture for you to go off into nature. Please return back in thirty minutes, that is (name the exact time). If you don't have a watch, be mindful of others and when you see people heading back, please do so as well. Please also do come back. Sometimes, participants want to stay out in nature longer. You can take as much as you want after this session, however, as part of the group experience, members worry if someone does not up and we will seek to ensure everyone is back. When you come back, please remain silent and mindful until everyone has rejoined the circle, then I will begin reading again and after, we will engage in a group dialogue. Any questions? All clear? Let's begin.

Read the following Chinese parable (cited by Daft \& Lengel, 2000, pp. 132-133): Back in the third century A.D., King Ts'ao sent his son, Prince T'ai, to the temple to study under the great master Pan $K u$. Because Prince T'ai was to succeed his father as king, Pan Ku was to teach the boy the basics of being a good ruler. When the prince arrived at the temple, the master sent him alone to the Ming-Li Forest. After one year, the prince was to return to the temple to describe the sound of the forest. When Prince T'ai returned, Pan Ku asked the boy to describe all that he could hear. "Master," replied the Prince, "I could hear the cuckoos sing, the leaves rustle, the hummingbirds hum, the crickets chirp, the grass blow, the bees buzz, and the wind whisper and holler." When the prince had finished, the master told him to go back to the forest to listen to what more he could hear. The prince was puzzled by the master's request. Had he not discerned every sound already? For days and nights on end, the young prince sat alone in the forest listening. But he heard no sounds other than those he had already heard. Then one morning, as the prince sat silently beneath the trees, he started to discern faint sounds unlike those he had ever heard before. The more acutely he listened, the clearer the sounds became. The feeling of enlightenment enveloped the boy. "These must be the sounds the master wished me to discern," he reflected. When Prince T'ai returned to the temple, the master asked him what more he had heard. "Master," responded the prince reverently, "when I listened most closely, I could hear...

Stop reading the story. Pause, and silently gesture for students to go off. After the thirty minutes is done, when everyone returns silently to sit in the circle, start reading again.

When Prince T'ai returned to the temple, the master asked him what more he had heard. "Master," responded the prince reverently, "when I listened most closely, I could hear the unheard-the sound of flowers opening, the sound of the sun warming the earth, and the sound of the grass drinking the morning dew." The master nodded approvingly. "To hear the unheard," remarked Pan Ku, "is a necessary discipline to be a good ruler. For only when a ruler has learned to listen closely to the people's hearts, hearing their feelings uncommunicated, pains unexpressed, and complaints not spoken of, can he hope to inspire confidence in his people, understand when something is wrong, and meet the true needs of his citizens. The demise of states comes when leaders listen only to superficial words and do not penetrate deeply into the souls of the people to hear their true opinions, feelings, and desires."

Debrief the exercise by asking the following: What did you hear in nature? How does this connect to your leadership? Enjoy the dialogue and what emerges; connecting it back to course learning objectives.

114 Journal of Leadership, Accountability and Ethics Vol. 16(5) 2019 


\section{What to Expect}

Students often have a profound experience when doing this exercise. What I have found is that by going out in nature, participants have a chance to reconnect with who they are. They hit the pause button on the constant demands and information that bombards them throughout their daily life. In this way, they can gain new insights while benefitting from the restorative power of nature. As a result, participants can feel a renewed sense of well-being and connection to the Earth.

Furthermore, deeper bonds may form between participants as they share their insights in the circle debrief. Students are always invited to share with the clear message that it is an invitation. No one has to share. Some choose not. One time, I had a student who spent the whole time in nature on his phone doing email. During the debrief, he stood on the edge of the circle listening as others shared. He was so moved that he ended up breaking down in tears, saying that he initially thought that the exercise was frivolous but now realized that he had cheated himself by not doing it. Another time, an Indigenous student approached me afterward to let me know that before the session she was planning to quit the program because she felt that she did not belong. However, she now felt connected to her peers as well as reconnected to herself and her ancestors. Colleagues have also told me that students have written about the profound experience in their reflective papers. Be prepared to be moved by the depth and range of experiences. 